\title{
Project and E-Learning Teaching Methods and Students Skills Acquisition in Electrical Installation Works in Technical Colleges in Akwa Ibom State
}

\author{
Dr Nsikak-Abasi Udofia
}

Dr Aniefiok Edet Udofia

Faculty of Education, University of Uyo, Uyo

P.M.B. 1017. Akwa Ibom State, Nigeria.

\section{Doi:10.5901/ajis.2013.v2n2p105}

\begin{abstract}
The purpose of this study was to determine the effects of e-Learning and project methods on acquisition of students' skills in Electrical Installation works in Technical colleges in Akwa Ibom State. The design of the study was a non randomized pretest, posttest control design. The population of 90 electrical electronics students from the two Technical colleges in Akwa Ibom State was used for the study. A researcher made instrument titled Skill Acquisition Test (SAT) was used for the study. The reliability index of the instrument was 0.79. It consisted of 35 items. The statistical tools used for the analysis were mean and Analysis of covariance. The findings of the study included that there was a significant difference between the effects of e-Learning and project methods of teaching on students' acquisition of skills in electrical installation works. The project method group performed better than the e-Learning group. The study recommended the use of the project method in teaching electrical installation but in line with modern demand advice that workshops should be organized by stakeholders in Education to acquaint teachers with skills in Information Communication Technology (ICT) for them to impact more positively on the students.
\end{abstract}

Keywords: Teaching methods, e-Learning method, Project method, Technical education, Skills acquisition

\section{Introduction}

The project is a versatile teaching method which facilitates teaching and assessing learners' performance simultaneously without impacting negatively on the learner who learns independently. In project method, the teacher serves as a resource person or a guide eager to share his expertise with the learners. The ability to think is developed in the learners who also develop skills through practices and successes in solving problems. The teacher brings his wealth of experience, skills and knowledge of the tools, equipment and processes to bear on such learners. He helps direct the manipulative and construction work by showing, telling and demonstrating as needed instead of authoritative issuing instructions. The project has evaluation inbuilt at the onset of the project, the start, the execution stage and till the completion of the finished project. Project evaluation is to investigate if the expected goals have been achieved at any stage of the project(Nsa,2002). It is important educationally, for a learner to be able to plan his/her work properly, then execute the plan skillfully. Improvement of learners' ability to handle problem-solving situations is encouraged by the use of the project method (Nsa,2002).

The project method possesses some advantages and disadvantages. The project method helps learners to do or manipulate things in their natural setting. The learners are made to learn through practical experiences. Project method provides purposeful activities on the part of the learners as they are kept busy by the project. It makes learning real and practical and therefore makes easy task for the pupils or students. Individual learner is able to make contributions towards the successful execution of their task.

It caters for the interest of learners as they naturally engage in carrying out interesting activities. The learners are able to discover or learn by themselves a lot of things. Students learn much more in project work than in demonstration or normal classroom teaching. This is because the learners work on their own and they rely on their own results. It serves a lot of teacher's effort and prevents the teacher tendency to dominate the lesson as in the case of demonstration and expository methods. Project increases enthusiasm and natural interest of the learners. The knowledge gained via project helps learners to understand and related concepts with subjects. It gives more responsibility to the learners and increases 
the scope of their initiatives. It encourages independence of thoughts, originality of thoughts and logical thinking of the learners. It promotes behavioural changes.

The project method, however, has some shortcomings $(\mathrm{Nsa}, 2002)$. It is difficult to carry out a project. It requires a lot of resourcefulness and experience by teachers to organize successfully and closely supervise learners in a project. It is time consuming on the part of students and teachers It is cost intensive, for purchasing the materials for the project. It requires specialized skills and experience which the teachers need to have.

Electronic learning or e-learning on the other hand is a type of education where the medium of instruction is Information Communication Technology (ICT) based. e-learning has to do with the use of tools such as computer, television, radio, faxes, satellites, CD ROM, internet, intranet or cell phones for the dissemination of information. In USA, e-learning is defined as a planned teaching/learning experience that uses a wide spectrum of technologies, mainly internet or computer based to reach learners. An e-learning approach has played a pivotal role in improving flexibility and quality of education training. E-learning is adopted in academic environments such as Colleges and Universities to reach out to students using alternative educational delivery systems for long distance learning. The video, CD ROM, Computer or internet based asynchronous learning are all delivery systems experimenting e-learning in one way or other.

Lately in most Universities, e-learning facilities are used for online Registration and admission formalities. ELearning is used to define specific mode to attend a course or programmes of study for on line students who rarely, if ever, attend face to face interaction with lecturers or other on-campus access to educational facilities. E-learning empowers people to know more and learn faster with less cost. It harnesses the power of information technology and knowledge. The e-learning and mobile learning are fast in delivery in education.

There is growing emphasis in e-learning skills development. e-learning, is the best practices for learning in new economy nations. Networking and Computers can be used anywhere or anytime for information delivery, learning objects and personalization. The e-learning via video is very stimulating and students use their visual senses and also participate in various activities. Research on pedagogical showed that video arouses students' interest together with the dynamic and rich information that it offers. The quality of picture and the flexibility makes the use of video particularly attractive. Video facilitate teacher's work. They concluded that video enhances learning and that video can be engaging, entertaining and provoking. They asserted that a short video can replace long convoluted text passages. Video is a natural choice for some learning activities, such as conversation in a foreign language or analyzing news events in social studies. Information presented by video may be more memorable to learners due to its visual details and its emotional impact.

The application of e-learning facilitates effective teaching and learning. Collaborative e-learning tool is an effective learning tool. It facilitates psychomotor skills acquisition. It fosters student analysis skill, critical thinking, idea generation and originality. A survey conducted by Bonk (2002) on e-learning indicated collaboration as very effective and interactive and thus enhances communication and skill acquisition among learners. In addition, the survey also pointed out that collaborative e-learning tool nurture learners brainstorming, understanding and skill acquisition. E-learning, can promote knowledge transfer through expert demonstration or modeling and immediate learner application. Smith (2002) carried out e-lab experiment based on inquiry and cooperative e-learning and reported that students learning are more efficient and effective. Furthermore that e-learning collaboration among students not only increases learning effectiveness, but also teachers, and students' essential life skills. The author recommended the adoption and understanding of the principles of e-learning in technological settings.

Bonk (2002) and Smith (2002) reported advantages and disadvantages of e-learning method as follows; the advantages include: It is useful in long distance learning. It empowers learners with specific skills. The use of collaborative e-learning tool encourages sharing of knowledge, ideas, skill and experiences. E-learning allows for live classroom, on line and web based learning. e-learning eliminates the barriers of time and distance. E-learning empowers people to know more and learn faster with less cost. The use of animation (real life situation) in the presentation makes it, particularly attractive and interactive. It creates a universal learning and provides opportunities for people, companies and countries. The advantages of e-learning include; It facilitates teachers work, motivates and sustains student's interest and facilitates animation in learning (real life situation). It also creates an interactive training environment for cognitive and psychomotor skills. One of the disadvantages of e-learning is funding. The cost of purchasing computers and other elearning devices, tools and equipment is much. As not all e-learning content can be delivered through technology, infrastructure becomes a problem. This is therefore why it is important to find out the efficacy of project method and elearning in electrical installation. 


\section{Research Questions}

1. The effect of e-learning and project methods of teaching on students' knowledge of skills in Electrical Installation Works

2. The effects of e-learning and project methods of teaching on students' acquisition of Affective skills in Electrical Installation works.

3. The effects of e-learning and project methods of teaching on students' acquisition of practical skills in Electrical Installation works.

4. The effect of e-learning and project methods of teaching on students acquisition of skills in Electrical installation Works.

\section{Hypothesis}

1. The effect of e-learning and project methods of teaching on students' knowledge of skills in Electrical Installation Works is not significant.

2. The effects of e-learning and project methods of teaching on students' acquisition of Affective skills in Electrical Installation works are not significant.

3. The effects of e-learning and project methods of teaching on students' acquisition of practical skills in Electrical Installation works are not significant..

4. The effect of e-learning and project methods of teaching on students' acquisition of skills in Electrical installation Works is not significant.

\section{Methodology}

The design of the study was a non randomized pretest, posttest control design. This was because intact classes were used. The population of 90 electrical electronics students from the two Technical colleges in Akwa Ibom State was used for the study. A researcher made instrument titled Skill Acquisition Test (SAT) was used for the study. The reliability index of the instrument was 0.79 . The students in each school were split into two groups. One group was instructed using project while the other used group were instructed using the e-learning method. Both groups were administered pretest and post test. It consisted of 35 items. The statistical tools used for the analysis were mean and Analysis of covariance.

Table 1: The effect of e-learning and project methods of teaching on students' knowledge of skills in rewiring of electrical machine in Electrical Installation Works

\begin{tabular}{lccc}
\hline Groups & $\mathrm{N}$ & Mean & SD \\
\hline e-Learning & 50 & 8.58 & 2.71 \\
Project Method & 40 & 9.23 & 2.19 \\
Total & 90 & 8.87 & 2.50 \\
\hline
\end{tabular}

As shown in Table 1, the mean score for students in e-learning teaching method was 8.58 while those in project method group obtained a mean of 9.23 . This implies that students in project method performed better than those in e-learning method in knowledge of skills in Electrical Installation work.

Table 2: The effects of e-learning and project methods of teaching on students' acquisition of affective skills in Electrical Installation works

\begin{tabular}{lccc}
\hline Groups & N & Mean & SD \\
\hline e-Learning & 50 & 8.84 & 2.39 \\
Project Method & 40 & 9.69 & 2.21 \\
Total & 90 & 9.21 & 2.34 \\
\hline
\end{tabular}

As shown in Table 2, the mean score of students in e-learning teaching method was 8.84 while those in project method group scored a mean of 9.69 . This implies that students in project method performed better than those in e-learning method in affective skills in Electrical Installations works. 
Table 3: The effect of e-learning and project methods of teaching on students' practical of skills in Electrical installation Works

\begin{tabular}{lccc}
\hline Groups & $\mathrm{N}$ & Mean & SD \\
\hline e-Learning & 50 & 8.82 & 2.38 \\
Project Method & 40 & 9.68 & 2.20 \\
Total & 90 & 9.20 & 2.33 \\
\hline
\end{tabular}

As shown in Table 3, the mean score of students in e-learning teaching method was 8.82 while those in project method group scored a mean of 9.68. this implies that students in project method performed better than in e-learning method in practical skills in Electrical installation Works..

Table 4: Summary of Mean and standard Deviation of posttest Scores of students use of meters for measurement

\begin{tabular}{lccc}
\hline Groups & N & Mean & SD \\
\hline e-Learning & 50 & 9.12 & 2.27 \\
Project Method & 40 & 9.45 & 2.21 \\
Total & 90 & 9.27 & 2.23 \\
\hline
\end{tabular}

As shown in Table 4, the mean score of students in e-learning teaching method was 9.12 while those in project method group scored a mean of 9.45 . This implies that students in project method performed better than in e-learning method in Electrical installation Works

Table 5: ANCOVA of the effect of e-learning and project methods of teaching on students' knowledge of skills in Electrical Installation Works

\begin{tabular}{lccccc}
\hline Sources of variation & SS & df & MS & $\boldsymbol{F}$ & F-Significant \\
\hline Pretest (Covariate) & 135.01 & 1 & 135.01 & 35.52 & .000 \\
Main Effect & 16.84 & 1 & 16.84 & 4.43 & .038 \\
Model & 151.85 & 2 & 75.92 & 19.98 & .000 \\
Residual & 330.56 & 87 & 3.8 & & \\
Total & 482.41 & 89 & 5.42 & & \\
\hline
\end{tabular}

From Table 5 the calculated P-value was significant at 0.038 significance level for the main effect, this was less than the alpha level .05; therefore, the null hypothesis is rejected. This implies that there exist significant differences between the effect of e-learning and project methods of teaching on students' knowledge of skills in Electrical Installation Works.

Table 6: ANCOVA of the effect of e-learning and project methods of teaching on students affective skills in Electrical Installation Works

\begin{tabular}{lccccc}
\hline Sources of variation & SS & df & MS & $\boldsymbol{F}$ & F-Significant \\
\hline Pretest (Covariate) & 145.56 & 1 & 145.56 & 43.19 & .000 \\
Main Effect & 15.5 & 1 & 5.05 & 4.59 & .042 \\
Model & 150.61 & 2 & 75.30 & 22.34 & .000 \\
Residual & 292.99 & 87 & 3.37 & & \\
Total & 443.60 & 89 & 4.98 & & \\
\hline
\end{tabular}

From Table 6, the calculated P-value being significant at .042 for the main effect is greater than the alpha level. 05 . Therefore, the null hypothesis is rejected. This implies that there exists significant difference between the effects of elearning and project methods of teaching on students' acquisition of Affective skills in Electrical Installation works. 
Table 7: ANCOVA of the effect of e-learning and project methods of teaching on students practical skills in Electrical Installation Works

\begin{tabular}{lccccc}
\hline Sources of variation & SS & df & MS & $\boldsymbol{F}$ & F-Significant \\
\hline Pretest (Covariate) & 45.32 & 1 & 45.32 & 27.63 & .000 \\
Main Effect & 8.73 & 1 & 8.73 & 5.32 & .024 \\
Model & 54.05 & 2 & 27.02 & 16.47 & .000 \\
Residual & 143.35 & 87 & 1.64 & & \\
Total & 482.40 & 89 & 5.42 & & \\
\hline
\end{tabular}

From Table 7, the calculated F-value .24 of main effect is greater than the alpha level .05; therefore, the null hypothesis cannot be rejected. This implies that there exist no significant difference between The effects of e-learning and project methods of teaching on students acquisition of practical skills in Electrical Installation works is not significant.

Table 8: ANCOVA of the effect of e-learning and project methods of teaching on students' knowledge of skills in Electrical Installation Works

\begin{tabular}{lccccc}
\hline Sources of variation & SS & df & MS & $\boldsymbol{F}$ & F-Significant \\
\hline Pretest (Covariate) & 32.01 & 1 & 32.01 & 9.41 & .000 \\
Main Effect & 34.84 & 1 & 34.84 & 10.24 & .038 \\
Model & 145.85 & 2 & 75.92 & 22.32 & .000 \\
Residual & 296.56 & 87 & 3.40 & & \\
Total & 442.41 & 89 & 5.42 & & \\
\hline
\end{tabular}

From Table 8 the calculated $F$-value .038 of main effect is less than the alpha level .05; therefore, the null hypothesis is rejected. This implies that there exist significant difference between the effect of e-learning and project methods of teaching on students' acquisition of skills in Electrical installation Works is not significant.

\section{Discussion of Findings}

Project method of teaching enhances or facilitates student's skill acquisition. Nsa (2003) who conducted experiment on demonstration and project methods on secondary school students acquisition of production skills using t-test and mean statistics reported no significant difference in the psychomotor performance between the male and female students taught using project method. The project method of teaching helps students to develop originality of work in them and also allows the learners more flexibility and autonomy in deciding their own ways of problem solving.

On the design of installation building diagram for two bedroom house, the results indicated the e-Learning group performing better than the project method having a mean score of 10.20 and 9.30 respectively. The results further showed a significant difference between the e-Learning and project methods of teaching on student's acquisition of psychomotor skills in designing electrical wiring building

Erickson (2000) reported that the design of electrical installation building diagram was based on a known set of standards that serves as reference code and guide to wiring methods. Stanb (2000) who reported the use of AutoCAD noted that the AutoCAD Granddad addressees each room individually on the basis of their characteristics and requirement for consideration and special purpose household electrical wiring diagrams, mostly in regard to household lighting design. The Granddad having met the owner's wishes further can make a translation in symbol that can easily be understood clearly by the users. In some cases the Granddad asks questions to make sure that adequate provision and lighting are provided to meet the standards methods and students acquisition of skills in rewinding of electrical machine. Ndukwe (1985) who conducted investigation on the performance of students in both expository and project methods reported a significant achievement in favour of project method. The study also indicated that project method had better performance/ retention than expository method of teaching.

Another result on preparation of winding coils indicated mean scores of 9.68 and 8.82 for both. Project method and e-Learning teaching methods respectively. This means score showed that project method group performed better than the e-Learning group. The findings also revealed a significant difference between e-Learning group and project group acquisition of psychomotor skills in electrical installation. Ndukwe (1985) who conducted investigation on the 
Performance of students in both expository and project methods reported a significant achievement in favour of project method. The study also indicated that project method had better performance/ retention than expository method of teaching.

Another result on preparation of winding coils indicated mean scores of 9.68 and 8.82 for both project method and e-Learning teaching methods respectively. This means score showed that project method group performed better than the e-Learning group. The findings also revealed a significant difference between e-Learning group and on the issue of testing of continuity of circuits; the results indicated that the students in the project method group performed better than those of the e-Learning group having mean scores of 6.15 and 5.56 as well as standard deviation of 1.66 and 1.30 respectively. The results further showed a significant difference between the effects of e-Learning and project methods of teaching on student's acquisition of psychomotor skills in testing of continuity in a completed rewound machine. An index of 0.21 indicates a low relationship between the teaching methods. The result also showed 27 per cent representing the total percentage variance in the acquisition of psychomotor skills in testing of continuity of circuits in electrical installation works.

There was a non significant difference between the effects of e-Learning and project methods of teaching on students acquisition of psychomotor skills in the use of meter for measuring of electrical quantities in electrical installation works There was is a significant difference between the effects of e-Learning and project methods of teaching on students acquisition of psychomotor skills in testing of continuity In a completed rewound machine in electrical installation works.

\section{Conclusions}

On the basis of the findings from the study, the following conclusions were made:

1. Students exposed to learner project method method of teaching performed better than those in the e-Learning in the use of correct tools in Electrical Installation Works.

2. Students exposed to project method of teaching performed better compared to the performance of those in the e-Learning group in terms of acquisition of skills in of electrical in Electrical Installation Works

\section{Recommendations}

1. The Federal Government, Ministry NGOS, companies and other stake holds in Education should help to provide educational facilities, equipment's machine and tolls to enhance the effective teaching of students for the acquisition of entrepreneurial skills for self reliance.

2. Awareness should be created in Technical Colleges on the importance of project and e-learning via information communication Technology (ICT) to improve student's performance and acquisition of employable skills for a better living.

3. The teacher should adopt both e-learning and project methods for the teaching of students for acquisition of psychomotor skills in the various areas.

4. Technical Teachers should acquire skills in the use of AutoCAD for effective and efficient teaching of skills.

\section{References}

Aina O. C. (1991). Technical and Vocational Training as a Strategy for Technical Development. The Nigeria Teacher: A Journal of Teacher Education, 1 (1), 5-14.

Akpan M. P. (1998). The Place of Vocational Education Towards Self Reliance in Akwa Ibom State. Nigerian Journal of Vocational Teachers Education, 1(1) 32-37.

Akpan, G. A. (2001). Instructional Techniques Preferences for Teaching Essential Work Skills in Technical Education, Nigerian Journal of Vocational Educations, 3(1) 1-6.

Akubuiro, I. M. \& Joshua M. T. (2004). Self Concepts, attitude and Achievement of Secondary School Students' in Science Retrieved August 3, $2005 \mathrm{from} \mathrm{http} / \mathrm{www}$ : utilities/mom/Science \%20 Education \%20 in Nigeria htm.

Altbach, P. G. \& Davis, T. M. (1999). Global Challenged Improvement. The Nigeria Teacher Today, 1(2) 12-12.

Boch, K. A. (1993). What are the Computer Realities in the Classrooms of the 90s. Current Issues in middle Level Education, 2(1), 9-15.

Fletcher, W. E. \& Deeds. J. P. (1991). Factors Preventing Micro Computer Use Among Secondary Agriculture Education Teachers in the United States Proceeding of Eighteenth Annual National Agricultural Education Research Method, Los Angeles, 229-237. 
Nsa, E. O. (2002). Effects of Demonstration and Project Methods of Teaching on Senior Secondary Students' Skill Acquisition in Vegetable Production. Journal of Education Innovator 1(1), 97-95.

O. B. U. (1990), Instructional techniques preferences for teaching Essential Work Skills in Technical Education. Nigeria Journal of Vocational Education 3 (1), 1-6.

Sakamoto, T. (2002). E-learning and Educational Innovation in Higher Education in Japan. Educational Media International (1) 9-16.

U. I. C. (1991), Technical and Vocational training as a Strategy for technical Development. The Nigeria teacher. A Journal of Education 1 (1), 5-14 
